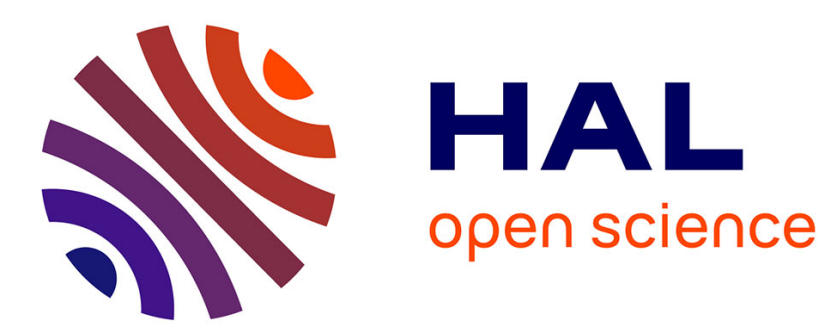

\title{
Gas market developments and their effect on relations between Russia and the EU
}

\author{
Sadek Boussena, Catherine Locatelli
}

\section{To cite this version:}

Sadek Boussena, Catherine Locatelli. Gas market developments and their effect on relations between Russia and the EU. OPEC Energy Review, 2011, 35 (1), pp.27-46. halshs-00578136

\section{HAL Id: halshs-00578136 \\ https://shs.hal.science/halshs-00578136}

Submitted on 18 Mar 2011

HAL is a multi-disciplinary open access archive for the deposit and dissemination of scientific research documents, whether they are published or not. The documents may come from teaching and research institutions in France or abroad, or from public or private research centers.
L'archive ouverte pluridisciplinaire HAL, est destinée au dépôt et à la diffusion de documents scientifiques de niveau recherche, publiés ou non, émanant des établissements d'enseignement et de recherche français ou étrangers, des laboratoires publics ou privés. 


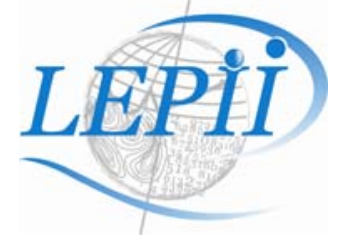

LABORATOIRE D'ECONOMIE DE LA PRODUCTION ET DE L'INTEGRATION INTERNATIONALE

UMR 5252 CNRS - UPMF

\section{CAHIER DE RECHERCHE \\ $\mathrm{N}^{\circ} 38$ ENG}

Gas market developments and their effect on relations between Russia and the EU

\section{Sadek Boussena Catherine Locatelli}

octobre 2010 



\title{
Gas market developments and their effect on relations between Russia and the EU
}

\author{
Sadek Boussena* and Catherine Locatelli** \\ * LEPII-EDDEN, Université de Grenoble, CNRS, BP 47, F-38040 Grenoble cedex 9, tel 33 (0)4 5652 \\ 8570 , \\ fax 33 (0)4 565285 71, Email: sadek.boussena@upmf-grenoble.fr \\ ** LEPII-EDDEN, Université de Grenoble, CNRS, BP 47, F-38040 Grenoble cedex 9, tel 33 (0)4 56 \\ 5285 70, fax 33 (0)4 565285 71, Email: catherine.locatelli@upmf-grenoble.fr
}

October 2010

\begin{abstract}
The changes on the EU gas market are likely to affect Europe's relations with its natural gas suppliers who are facing increasing competition. Heading this list of producing countries is Russia. Gas relations between Russia and the EU are characterized by strong interdependence. But these relations are currently being hampered by serious lack of understanding, making it difficult for the two parties to reach agreement on a new energy partnership. The aim of this article is to analyse the effects of this new European gas context on Gazprom's strategy and how the issues of energy security and cooperation between Russia and the EU will be affected by this new order.
\end{abstract}

Russia is by far the European Union's most important gas partner. The country's gas company Gazprom provides the EU with 40 per cent of its natural gas imports, which account for 57.6 per cent of the company's gas exports. However, despite the strategic importance of relations between the EU and Russia, serious lack of understanding between the parties is currently making it impossible for agreement to be reached on a new energy partnership. Until now, the EU has been pursuing its objectives of liberalizing the gas industry, creating a single market and ensuring supply security. At the same time, Russia, as the EU's main supplier, has been seeking to consolidate its position and expand its outlets, encouraging Gazprom to acquire more assets downstream in the European gas chain.

The considerable reduction in Europe's gas demand in 2009, the EU's adoption of the third energy package, which provides additional impetus to the opening up of the European market, and recent developments in the world market are upsetting the gas market order. All of these changes are likely to affect Europe's relations with its natural gas suppliers, who are facing increasing competition. Heading this list of producing countries is Russia. So what effect is this having on Gazprom's strategy with respect to the European market, a strategy thus far dominated by a policy of downstream integration and export market diversification? How will the issues of energy security and cooperation between Russia and the EU be affected by this new order? In this article, we will endeavour to shed light on these questions. 


\section{Gazprom's response to EU gas market liberalization}

The liberalization of EU gas markets driven by the gas directives of 1998 and 2003, then by the third energy package of 2009, implies a major organizational and institutional transformation of the gas industry in the EU countries. The process involves de-integration of national monopolies along with third-party access (TPA) in segments of an industry where transmission/distribution operates as a natural monopoly. Liberalization will result in greater competition among suppliers, and more spot market sales and short-term transactions. It will also increase the exposure to "price risk" and “volume risk" of Europe's gas suppliers.

Gazprom is adopting a number of strategies to deal with this increasingly uncertain environment. The company intends to maintain its long-term contracts as a way of guaranteeing its sales to Europe. But it is also attempting to develop policies that will enable it to adapt to the changing situation, such as consolidating its outlets by gaining a foothold in the European gas market, increasing its export routes to Europe, and diversifying its export markets to Asia and the US. However, the various responses being developed by Gazprom in response to the changing European market require different time frames. The strategy of acquiring existing assets or creating subsidiaries in Europe will obviously take less time to implement than setting up competitive projects involving exports to Asia. Diversification can only take place in the medium to long term given that it will be necessary for Russia to develop the gas fields in eastern Siberia.

\section{I.1 Uncertainty concerning long-term contracts}

Under the former system, long-term take-or-pay (TOP) contracts were a way of sharing the risks related to prices and volumes between producers and importers (Boussena, 1999) and in doing so they helped stabilize relations between the parties. Until now, such contracts, with a few amendments, have generally resisted the upheavals of the European market and continue to provide a basis for most of the EU's imports. But as the liberalization process intensifies, the incompatibility between the two approaches is becoming more evident. Today, one of the possible sources of friction between the EU and Gazprom (and probably other suppliers as well) is the possible re-examination of these long-term contracts or amendments to some of their clauses that are deemed to be incompatible with the flexibility needed for the operation of a single natural gas market (Chevalier and Percebois, 2007). Among the "questionable" clauses are those concerning the duration of contracts, the price indexation formula, and flexibility regarding minimum and maximum quantities the purchaser must take. Negotiations will probably take place with a view to modifying some of these clauses (with the introduction of a spot price in the indexation formula) ${ }^{1}$ while others, such as the final destination clause, have already been removed. Even thought the debate is far from over in Europe (Hauteclocque and Glachant, 2009; Rious, 2009), the EU authorities appear to consider these TOP contracts to be contrary to the Union's competition policy (EC, 2008; Percebois, 2008), seeing them as major barriers to the entry of potential new partners and believing that they inhibit development of the liquidity needed in the markets. The risk is that

\footnotetext{
${ }^{1}$ In certain cases, components of formulas for pricing part of the gas supply will include market prices for electricity, or prices for coal, which can be a substitute for gas in electricity generation. In a few years time they could include spot prices in continental Europe, provided these markets are sufficiently liquid. Liberalization will thus quite likely lead to changes in price formation.
} 
the markets will become divided, which is counter to the creation of a single market for gas, the second objective of EU energy policy (Talus, 2007).

For Gazprom as for other external suppliers, long-term contracts are a factor in securing demand and consequently in securing the investment required upstream. The financial risk related to the enormous investment needed to develop new production zones is limited by the fact that TOP contracts guarantee outlets over the long term. Gazprom has frequently pointed out that the huge gas reserves in Yamal province can only be developed if it continues to sign long-term TOP contracts with European countries. Its primary goal is to try to maintain such long-term contracts in order to guarantee its sales in Europe. In fact it has had a certain degree of success, having concluded new TOP contracts with E.ON, ENI, GDF-Suez, Wintershall and OMV (cf. Table 1).

Table 1: Long-term contracts concluded by Gazprom with European partners between 2005 and 2009 (new and renewed)

\begin{tabular}{|l|c|c|c|}
\hline \multirow{3}{*}{ Gountry } & Company & Duration of contract & Quantities \\
\cline { 2 - 4 } & E.ON-Ruhrgas (1) & $2011-2036$ & $100 \mathrm{Gm}^{3}$ \\
\cline { 2 - 4 } & E.ON-Ruhrgas & $2020-2035$ & $300 \mathrm{Gm}^{3}$ \\
\cline { 2 - 4 } & E.ON & $2009-2020$ & $90 \mathrm{Gm}^{3}$ \\
\hline Austria & WIEH & $2014-2031$ & $7.5 \mathrm{Gm}^{3} / \mathrm{yr}^{3}$ \\
\hline Bulgaria & OMV (2) & $2012-2027$ & $3 \mathrm{Gm}^{3} / \mathrm{yr}^{3}$ \\
\hline Denmark & Bulgargaz (3) & $2011-2030$ & $22 \mathrm{Gm}^{3} / \mathrm{yr}^{3}$ \\
\hline Italy & Dong Energy (4) & $2011-2031$ & $12 \mathrm{Gm}^{3} / \mathrm{yr}^{3}$ \\
\hline France & ENI (5) & $2017-2035$ & $2.5 \mathrm{Gm}^{3} / \mathrm{yr}$ \\
\hline Poland & GDF-Suez (5) & $2017-2030$ & $11 \mathrm{Gm}^{3} / \mathrm{yr}$ \\
\hline Czech Republic & GDF-Suez (6) & $2010-2040$ & $9 \mathrm{Gm}^{3} / \mathrm{yr}$ \\
\cline { 2 - 4 } & PGNiG & $2009-2037$ & $0.55 \mathrm{Gm}^{3} / \mathrm{yr}$ \\
\hline Romania & RWE Transgaz (7) & $2014-2035$ & $4.5 \mathrm{Gm}^{3} / \mathrm{yr}$ \\
\cline { 2 - 4 } & Vemex (8) & $2008-2012$ & $4.5 \mathrm{Gm}^{3} / \mathrm{yr}$ \\
\hline Slovakia & WIEH & $2012-2030$ & $6.5 \mathrm{Gm}^{3} / \mathrm{yr}$ \\
\hline
\end{tabular}

Notes: (1) incumbent operator and via NordStream pipeline; (2) incumbent operator, 25 per cent marketed by Centrex and GWh controlled by Russian interests; (3) incumbent operator; (4) via NordStream pipeline; (5) incumbent operator. ENI has agreed that Gazprom can sell $3 \mathrm{Gm}^{3} / \mathrm{yr}$ directly on the Italian market. The agreements signed are aimed at defining a partnership based on asset swaps with Gazprom: a 10 per cent stake in ENIPower in exchange for shares in a gas field, and the creation of a joint marketing company in exchange for a stake in a gas field; (6) incumbent operator and via NordStream pipeline; (7) incumbent operator; (8) Vemex, marketing company in which Gazprom has a 33 per cent share.

Sources: Tonjes, De Jong (2007); Finon, Locatelli (2006); “Gazprom starts to compete against its own long-term contracted supplies in the Czech downstream market”, Gas Matters, Nov-Dec 2007, pp. 24-25; Argus FSU Energy, 5 March 2010.

\section{I.2 Gazprom - adapting through downstream integration}

To consolidate and better develop its exports, a natural gas supplier may be tempted to seek greater participation in downstream activities, penetrating at least as far as the wholesale trade sector. By acquiring assets in transmission and distribution companies, and even in gasconsuming industries (such as electricity generation), producers have the opportunity to sell their resources without having to face competition on wholesale markets (Eikeland, 2007). Downstream integration also provides producers with the opportunity to increase their profits by capturing the profit margins of middlemen in the various downstream segments. At least, they can profit themselves from low gas prices as a producer/seller of power for example. 
Gazprom's policy of acquiring assets abroad (in regions to which it exports), which it has been doing since the end of the 1980s, falls within this type of strategy, the aim of which is to gain as much access as possible to end-consumers. Gazprom has stated its ambition to obtain a 10 per cent direct share of the French and UK markets by 2010 and 20 per cent by 2015. It has expressed similar goals with respect to Italy and the Czech Republic. The company started by setting up joint ventures in transmission, marketing and trading with incumbent operators in Europe. It then went on to create marketing subsidiaries in certain European countries and/or to acquire minority or majority stakes in local companies. This more recent method of penetrating markets is still not very widespread, although acquisitions have already be made in some countries, such as the United Kingdom, Italy, Hungary, Austria and in particular the Baltic states (Locatelli, 2008).

\section{Box 2: Gazprom's main Joint ventures, acquisitions among its European Union partners and its main subsidiaries in the EU (end of 2009)}

\begin{tabular}{|c|c|}
\hline Countries & Company \\
\hline Austria & $\begin{array}{l}\text { Gazprom will have right to sell directly to customers through subsidiary } \\
\text { GWH and Centrex (25\% held by Gazprom) } \\
\text { GWH : JV with OMV, marketing et trading }\end{array}$ \\
\hline Germany & $\begin{array}{l}\text { Wingas : JV with Wintershall, Transportation and sales } \\
\text { WIEH : JV with Wintershall, Sales, marketing and storage } \\
\text { WIEE : JV with Wintershall, sales of Russian gas to Central and South } \\
\text { European countries }\end{array}$ \\
\hline Finland & $\begin{array}{l}\text { Gasum : JV with Fortum and E. ON, distribution } \\
\text { North Transgas OY : JV with Forum ; transportation (gas pipeline) }\end{array}$ \\
\hline France & $\begin{array}{l}\text { Gazprom Marketing and Trading France SAS, Gazprom's subsidiary to sell } \\
\text { gas directly to french consumers } \\
\text { Fragas : JV with GDF-Suez, distribution et trading }\end{array}$ \\
\hline Hungary & $\begin{array}{l}\text { Acquisition of share in E.ON Foldag Storage and E.ON Foldaz and in } \\
\text { regional gas and electricity suppliers as part of a deal with E.ON concerning } \\
\text { its holdings in MOL } \\
\text { Panrusgaz : JV with Mol, Marketing and distribution }\end{array}$ \\
\hline Italy & $\begin{array}{l}\text { Possibility of acquisition of } 10 \% \text { stake in ENIpower with direct sales of gas } \\
\text { for electricity production }\end{array}$ \\
\hline Poland & $\begin{array}{l}\text { EuroPolGaz: JV with PGNiG, Transportation (Yamal-Europe pipeline in } \\
\text { Poland) }\end{array}$ \\
\hline Czech Rep & $\begin{array}{l}\text { Vemex : JV, Gazprom is a shareholder by the mean of Centrex Energy, } \\
\text { Trading of Russian gas }\end{array}$ \\
\hline Romania & $\begin{array}{l}\text { Winrom gas SA : JV WIEE-Distrigas, implication of Gazprom by the mean } \\
\text { of WIEE, sales of gas }\end{array}$ \\
\hline \multirow[t]{3}{*}{ United Kingdom } & Acquisition of share in gas distributor Pennine Natural Gas (PNG) \\
\hline & $\begin{array}{l}\text { Acquisition of gas distribution company NGSS (Natural Gas Shipping } \\
\text { Services) }\end{array}$ \\
\hline & $\begin{array}{l}\text { Gazprom Marketing and Trading, Gazprom subsidiary enabling Gazprom to } \\
\text { sell Russian gas directly in the UK }\end{array}$ \\
\hline Switzerland & WIEE : JV with Wintershall, marketing \\
\hline Estonia & $\begin{array}{l}\text { Acquisition of share (37.5\%) in marketing and transmission company Eesti } \\
\text { Gaas }\end{array}$ \\
\hline Latvia & $\begin{array}{l}\text { Acquisition of share (34\%) in marketing and distribution company Latvijas } \\
\text { Gaze }\end{array}$ \\
\hline \multirow[t]{2}{*}{ Lithuania } & $\begin{array}{l}\text { Acquisition of share (30\%) in transmission and distribution company Stella } \\
\text { Vitae }\end{array}$ \\
\hline & $\begin{array}{l}\text { Acquisition of share (37\%) in marketing and transmission company Lietuvos } \\
\text { Dujos }\end{array}$ \\
\hline
\end{tabular}

Source: Locatelli, C. (2008). 


\section{- the EU's response: the third energy package}

Some in the EU consider Gazprom's policy of seeking footholds downstream to be a threat to Europe's energy security, not least because the Russian State holds a major stake (51 per cent) in Gazprom's capital ${ }^{2}$. These parties are trying to discourage this practice in the EU by unbundling ownership of the gas chain or introducing the third country clause.

Discussions on the third energy package have highlighted a certain number of stumbling blocks between the EU and Gazprom. They concern the effect on producers of ownership unbundling imposed by the EU as part of gas industry de-integration. With unbundling, the various segments of the gas chain are separated in terms of their legal structure and for accounting purposes in order to avoid vertical integration, which is considered to be a barrier to the entry of new players. Unbundling first of all affects European gas companies and especially incumbent operators that are vertically integrated from production through to distribution. But it can also affect companies in producing countries, getting in the way of their strategies to enter the downstream sector. Although a final compromise has been reached, albeit less ambitious than the initial proposals of the European Commission ${ }^{3}$, a number of ambiguities still remain. It can be considered that the rules adopted in the third energy package mean that a producer and supplier such as Russia cannot also, at the same time, be a Transmission System Operator (TSO) in a member state (Willems et al, 2010).

The controversy has been intensified because of the third country clause, also known as the "anti-Gazprom clause". Under its provisions, if non-EU energy companies wish to operate in the EU, they must demonstrate that they do not pose any threat to EU energy security. The clause could appear as a serious barrier to potential foreign investment in the European energy sector.

\section{I.3 Increasing export capacities}

With its plan to construct new gas pipelines to Europe, Russia is expecting to ensure exports of the order of $200 \mathrm{Gm}^{3}$ to this zone by 2030. Two main supply routes are concerned: the Nord Stream, with a total capacity of $55 \mathrm{Gm}^{3}$ and the South Stream, with a capacity of $63 \mathrm{Gm}^{3}$ (Box 1). The Nord Stream pipeline project is well under way and the first line should be operational by the end of 2011. The South Stream project is still in the negotiation stage. These two export routes, in particular the Nord Stream, are a vital part of Russia's strategy to secure its exports to the European markets, particularly following the two gas disputes with Ukraine and more recently with Belarus. Passing under the Baltic sea, the Nord Stream is the first gas pipeline to link Russia with the natural gas markets of Western Europe. In the present context where there is a slump in demand from Europe, this pipeline may act as a partial substitute for exports that would otherwise be shipped via Ukraine. In this case, the project takes on a political as well as an economic flavour. Russia's objectives with the South Stream are much broader. While Russia is clearly aiming to diversify its export routes and expand its

\footnotetext{
${ }^{2}$ The UK government showed strong opposition to Gazprom's ambitions - supposed or real - to buy shares in British company Centrica.

${ }^{3}$ Each country may choose to opt either for ownership unbundling or for a structural organization in which an independent transmission system operator (TSO) is designated.
} 
sales, it is also trying to counter the Nabucco pipeline (Caspian gas), a project backed by the EU which sees it as a way of reducing its dependence on Russian gas.

\section{Box 1: Gazprom's projects for new export routes to Europe}

\section{Nord Stream}

A 1,220 km gas pipeline between Russia (Vyborg) and Germany (Greifswald) under the Baltic sea. The first line, with a capacity of $27.5 \mathrm{Gm}^{3}$ should become operational in October 2011 and the second, with a capacity of $55 \mathrm{Gm}^{3}$, by the end of 2012 .

The estimated total cost of the two pipelines is 8.8 billion euros.

The consortium is composed of Gazprom (51\%), E.ON (15.5\%), Wintershall (15.5\%), GDF-Suez $(9 \%)$ and Gasunie (9\%). Gazprom has already signed long-term contracts for delivery of $20 \mathrm{Gm}^{3}$ via the Nord Stream.

Initially, this pipeline was to be supplied with gas from the Shtokman field. However, for the first phase, only gas fields in western Siberia will be concerned.

\section{South Stream}

Gas pipeline between Russia and Central and Southern Europe via the Black Sea. This project is still in its early stages. The planned route will enable Russian gas to be delivered to Bulgaria. From there, the pipeline will be divided into two branches, one to Italy via Greece and the other to Austria via Slovenia, Hungary and Serbia.

The envisaged capacity is $63 \mathrm{Gm}^{3} / \mathrm{yr}$, in two pipelines, the first of which will have a capacity of $31.5 \mathrm{Gm}^{3} / \mathrm{yr}$.

The pipeline is expected to be on-stream in 2015.

The consortium is composed of Gazprom (51\%) and ENI (49\%). EDF could join the consortium with a $20 \%$ stake.

\section{I.4 Transcontinental competition between the major import markets}

Gazprom's policy of diversifying its markets is a way of responding to what it feels is Russia's over-dependence on the European market. The EU is currently its most profitable market, in particular compared with its domestic market (low government-regulated prices) and other CIS countries, where prices are considerably lower than those contracted with EU partners (Locatelli, op . cit.). This policy was especially encouraged at the beginning of the 2000s at a time when the Russian state was regaining control of the sector and when there was much talk about scarcity of resources in the long term and about competition between the major importing countries for access to hydrocarbon resources. The countries particularly concerned by this strategy of seeking alternative markets are Japan, China, South Korea, Asia in general, and also the US. For example, the Shtokman offshore field (Barents sea), which could have been developed with Europe in mind, might also be developed to a large extent to supply LNG to the US market. Pipeline projects to export gas to China could be supplied by reserves in eastern Siberia, which are a considerable distance from the European market (cf. Box 2). The gas fields in question are those in Kovykta (Irkoutsk region), Talakan and Chayandinskoye (Sakha Republic). This latter field could supply the projected Chayandinskoye-Khabarovsk-Vladivostok gas pipeline ${ }^{4}$. Certain reserves in western Siberia being developed as part of the Altaï project could also be devoted to supplying China. By announcing this strategy Russia is suggesting that the European and Asian markets will be facing competition, whereas in reality, so long as there is no real worldwide gas market, and

\footnotetext{
4 “Chayandinskoye decision due”, Argus FSUE, 21 May 2010.
} 
in view of transmission costs and prices, these reserves are relatively captive and can only be profitable in one of the two destinations. But if Russia succeeds in developing its Asian markets, it will obviously be better placed to exert influence on natural gas price formation at the international level (Boussena and Locatelli, 2005).

\section{Box 2: Gazprom's projects for export routes to China Three competing projects}

- Chayandinskoye-Khabarovsk-Vladivostok-China pipeline from the Chayandinskoye gas field: over $2,000 \mathrm{~km}$ in length and with a capacity of $30 \mathrm{Gm}^{3} / \mathrm{yr}$.

- Altaï project: Urengoi-Samotlor (western Siberia)-Novosibirsk-China: 2,800 km.

The agreement signed in 2006 between Gazprom and CNPC concerns $30 \mathrm{Gm}^{3}$ of exports to China. This project, which was updated in 2010, could be developed on a "loans for gas" basis, already tested by Russia with China for oil.

- Route parallel to the East Siberia-Pacific Ocean oil pipeline from Kovykta: 3,000 km with a capacity of $30 \mathrm{Gm}^{3}$. Of the projects examined, the Kovykta gas field has the largest reserves.

- Also further projects to export LNG from Sakhalin I, consortium headed by ExxonMobil: preliminary export agreement signed in 2006 with CNPC.

\section{Recent developments: new challenges for Gazprom}

While over the last few years we have witnessed a notable rise in gas delivery capacity to Europe from the Middle East, North Africa and Nigeria, the economic crisis that started in 2008 has led to considerable reductions in gas demand in most of the large EU states, which are the main importers of Russian gas (cf. table 3). Furthermore, the higher than expected growth in unconventional gas production in the United States seems to be creating a different situation from that of the early 2000s. In fact, while it is hoped that gas demand might rise again in the short to medium term thanks to renewed economic growth, the US market appears set to remain self-sufficient in the long term. In this case, large volumes of LNG that were originally destined for this market will most likely be redirected to Asia, where demand is still rising, and to Europe where these volumes are already starting to have an impact on prices. So a situation where expected pressure on future supply was leading to calls for greater investment in gas projects, notably from the EU, has given way to a market where supply is abundant and where buyers will most likely have an even stronger influence on prices.

Table 3: Gas demand of some European countries, 2008 versus 2009

\begin{tabular}{|l|l|l|l|l|l|l|l|}
\hline BCM & $\mathbf{2 0 0 8}$ & $\mathbf{2 0 0 9}$ & $\mathbf{2 0 0 9} / \mathbf{2 0 0 8}$ & $\mathbf{B C M}$ & $\mathbf{2 0 0 8}$ & $\mathbf{2 0 0 9}$ & $\mathbf{2 0 0 9 / 2 0 0 8}$ \\
\hline Germany & 98,0 & 92,6 & $-5.5 \%$ & Irland & 5,2 & 5,0 & $-3.8 \%$ \\
\hline Austria & 8,7 & 8,8 & $-1.2 \%$ & Italy & 84,9 & 78,1 & $-8.0 \%$ \\
\hline Spain & 38,2 & 33,9 & $-11.3 \%$ & Hungary & 13,1 & 11,3 & $-13.7 \%$ \\
\hline France & 46,1 & 44,5 & $-3.5 \%$ & Slovakia & 6,3 & 6,1 & $-3.2 \%$ \\
\hline Greece & 4,2 & 3,5 & $-16.7 \%$ & UK & 99,0 & 90,8 & $-9.0 \%$ \\
\hline
\end{tabular}

Source : IEA (2010).

This unexpected rise in delivery capacity to these two regions that import significant volumes of gas is bound to have an effect on Europe's suppliers, and thus principally on Russia. Greater competition among suppliers along with unused production capacity in Russia due to 
reduced demand may in the medium term exacerbate overcapacity. With the prospect of gas markets remaining in oversupply, it is reasonable to assume that buyers now have the upper hand, leaving Gazprom with less room to manoeuvre.

What can Russia do to reduce the negative effects of overcapacity on its export revenues? It could defend its prices by consulting with other producers through the Gas Exporting Countries Forum or attempt to keep its market shares in Western Europe. The first option could not provide a solution in the short term. In the second case, it would mean allowing Gazprom to agree to certain demands from its clients to revise contractual conditions. To avoid having to do this, Russia is considering other possible courses of action aimed in particular at limiting production growth or developing new export markets.

\section{II.1 Revising its export investment programme}

In the medium term, one possibility might be for Gazprom to revise its investment programme in order to limit growth in its gas production. Between 2002 and 2008, Gazprom received frequent criticism from within the EU for not investing sufficiently in order to stem the decline of those reserves already on-stream and for not investing in new projects. The company's ability to respect its long-term commitments was often called into question. This view, developed among others by V. Milov ${ }^{5}$ (and often reiterated by the IEA), had influenced discussions between the two parties. In the new context, this no longer applies.

The economic and financial crisis has led to a drastic drop in gas consumption in the EU and the CIS countries, and as a result Gazprom's exports fell by around 21 per cent in 2009. Not including those to the CIS ${ }^{6}$, Russia's exports amounted to $140.6 \mathrm{Gm}^{3}$ in 2009 compared with $158.8 \mathrm{Gm}^{3}$ in 2008. Adjustments on the Russian domestic market were also significant because of the slowdown in the country's economic growth. These two trends resulted in a 16 per cent drop in Russian gas output in 2009 and a readjustment of Gazprom's production scenarios up to 2012. The company predicts output for 2012 of the order of $543 \mathrm{Gm}^{3}$, which is still lower than in 2008 (cf. Table 4). It will not be until 2013 that production (567 Gm ${ }^{3}$ ) will be comparable to the level initially forecast for 2010. Revised estimates for 2010 in particular are considerably lower (down by $30 \mathrm{Gm}^{3}$ ).

Table 4: Gas production forecasts for Russia

\begin{tabular}{|l|c|c|c|c|}
\hline BCM & $\mathbf{2 0 0 8}$ & $\mathbf{2 0 1 0}$ & $\mathbf{2 0 1 1}$ & 2012 \\
\hline \multicolumn{7}{|c|}{ Gazprom (figures from Gazprom) } \\
\hline Previous estimates & 549 & 567 & 570 & \\
\hline Estimates 2009 & 549 & 507 & 510 & 533 \\
\hline Estimates 2010 & 549 & 519 & 529 & 543 \\
\hline \multicolumn{4}{|c|}{ Total Russian production (figures from Ministry of Economic Development) } \\
\hline Previous estimates & 664 & 647 & 660 & 675 \\
\hline New estimates & 664 & 623 & 630 & 649 \\
\hline
\end{tabular}

Source: « Gazprom upgrades output forecast ».- FSUE Argus, 11 juin 2010.

Russia is therefore no longer compelled - at least in the short term - to invest massively in renewing its gas fields and infrastructure in order to meet its contractual commitments and

\footnotetext{
${ }^{5}$ V. Milov forecast a gas deficit for Russia of $132 \mathrm{Gm}^{3}$ in 2010 (Milov, 2005), which tended to confirm the study by the Centre For European Policy Studies, which predicted a figure of $126 \mathrm{Gm}^{3}$ for 2010 (Riley, 2006).

${ }^{6}$ Gazprom's exports to the CIS rose to $67.6 \mathrm{Gm}^{3}$ in 2009 compared with $95.6 \mathrm{Gm}^{3}$ in 2008 .
} 
domestic market needs. Gazprom has revised its investment programme profoundly, in particular delaying production of the Bovanenko field (Yamal province), initially envisaged for 2011, until the end of 2012. Prospects of developing the Shtokman field appear much less certain in the middle term (Stern, 2009). Development of this gas field is directly linked to Russia's ambitions to export LNG to the US. But given the current situation in the US where natural gas spot prices are less than $5 \$$ /Mbtu, LNG exports would not be profitable. It therefore seems unlikely that that this gas field will go on stream before $2016^{7}$.

\section{II.2 Speeding up diversification into the Asian market}

Apart from supplying Japan and South Korea with LNG from the Sakhalin gas field, the only medium-term option for greater diversification (at least that can be justified economically) is the Asian market, and more specifically China. Even though certain constraints remain - lack of agreement on price indexation formulas used for long-term contracts ${ }^{8}$, the size of the infrastructures to be created and thus the considerable financial commitments ${ }^{9}$ - the changes taking place on the European gas market could persuade Gazprom to speed up its plans for diversification into the Asian market. These competing projects show that the Russian state and Gazprom have not defined a coherent policy.

Gazprom, which is bound by profitability constraints and must also develop natural gas consumption in the Russian Far-Eastern region, seems to favour the projects to build pipelines from fields in eastern Siberia and in particular from the Chayandinskoye field close to China's eastern border. However, it is unlikely that this field will be developed before 2016, and probably even later ${ }^{10}$. Resumption of negotiations between Gazprom and the China National Petroleum Corporation (CNPC) on the Altaï project, a pipeline fed by gas reserves in western Siberia, would seem to suggest that some members of the Russian government (in particular I. Sechin ${ }^{11}$ ) would like to see gas relations between Russia and China develop more rapidly, with deliveries of 30 BCM starting in $2015^{12}$.

However, in the short term at least, Asia can only be a complementary export destination and will not be competing with the EU for gas exports. The volumes concerned are between 50

\footnotetext{
7 “Off the drawing board”, Argus FSUE, 16 April 2010.

${ }^{8}$ The Chinese government wants to include coal prices on the Chinese market in the indexation formula used in any long-term contracts concluded with Russia, rather than just oil prices. Since China's domestic coal prices are very low, this would lower the price of natural gas exports from Russia. Although its domestic prices have increased significantly over the last few years, China cannot envisage paying import prices comparable to those practised on European markets. 'Russia misleads on China gas talks’ Argus FSU Energy, 23 November 2007.
}

${ }^{9}$ In the three potential production zones in eastern Siberia, the Republic of Sakha, and the Irkutsk and Krasnoyarsk regions, reserves are estimated at between 3.7 and $5.3 \mathrm{Tm}^{3}$ (proven) and over $50 \mathrm{Tm}^{3}$ (potential). Their development, along with the creation of long-distance gas pipelines, would however require considerable financial commitments. A number of projects are being envisaged. The Kovykta and Chayandinskoye fields could supply the Sakha-Yakoutie-Khabarovsk-Vladivostok pipeline. But these fields are not expected to go into production before 2017. From 2014, this pipeline could be fed by the Sakhalin 1 gas field.

10 “West Siberia-China link back on the agenda”, Argus FSUE, 30 July 2010.

${ }^{11}$ I. Sechin is Deputy Prime Minister in charge of energy questions. He is also chairman of the Board of Directors of oil company Rosneft, an important point to note given Rosneft's gas objectives in Asia.

12 “China ponders Russian gas”.- Petroleum Argus, 23 Aug. 2010 ; “Russian firms sign China deals” Petroleum Argus, 1 october 2010. 
and $70 \mathrm{Gm}^{3}$ compared with $157 \mathrm{Gm}^{3}$ for Europe in 2008 (before the crisis) ${ }^{13}$. This question of diversification and of opening up new markets for Russian gas exports - especially in light of the development of Russian-Chinese relations - will be a key factor in relations between Europe and Russia ${ }^{14}$. Moreover, apart from where the Sakhalin production units are concerned, Gazprom's strategy of diversifying through the LNG option, in particular by exporting to the US market, appears to be compromised at least for the short-to-medium term $^{15}$. As we underlined, the profitability conditions do not seem to be in place to enable Russia to envisage exporting massive volumes of LNG.

\section{II.3 Defending its market shares in Europe}

The changes that have been taking place in the European gas market could call into question Gazprom's stance with regard to its contractual conditions, and at the very least may force the company to agree to certain amendments, including renegotiating long-term contracts in order to add greater flexibility and preserve its market shares ${ }^{16}$. As is the case for all gas producers, the company must find a new balance between prices and volumes.

Two issues are at stake in the negotiations between Gazprom and European gas companies concerning changes to long-term contracts. First, given the substantial difference between the two price categories, the gas company is called to take spot price indices on the European market into account when formulating contract prices. In fact, whereas prices in TOP contracts have generally followed the evolution of the price of crude or petroleum products, to which they are indexed, spot prices of natural gas and LNG have collapsed due to the oversupply of gas in a gas-gas competition on the spot markets. Consequently, there is now a substantial difference between spot market prices and long-term contract prices ${ }^{17}$. Even though the volumes sold on the free market are far smaller than those sold in long-term contracts, this imbalance - if it persists - is likely to pose problems for the various parties, particularly on the wholesale market which is developing rapidly. It will also be necessary to renegotiate the minimum quantities to be taken under the terms of the TOP contracts in light of the reduction in demand on the European markets.

A certain number of European gas companies, including E.ON, Wintershall (through its subsidiary Wingas), ENI and GDF-SUEZ have been negotiating with Gazprom to have their

\footnotetext{
13 The figure of $50 \mathrm{Gm}^{3}$ was announced by S. Komlev. "Interview: Sergei Komlev, Gazprom Head of Contract Structuring and Price Formation”, Gas Matters, March 2010, pp. 17-19. The figure of $70 \mathrm{Gm}^{3}$ was also given by Gazprom following the agreement concluded with CNPC in 2009. 'Russia's Gas Plan New Routes, allies and Markets', Petroleum Intelligence Weekly, 19 April 2010.

${ }^{14}$ As underlined by T. Gomart (2010), Russia often uses the Chinese option to obtain concessions from western partners.

15 “Gazprom Price Stance Weakens As LNG Gains”, Petroleum Intelligence Weekly, XLIX (10), 8 March 2010.

${ }^{16}$ In Europe there is a considerable gap between natural gas prices on spot markets and the oil-indexed prices in long-term contracts. Between August 2008 and November 2009, spot prices were on average about 50\% lower than prices indexed to crude and petroleum product prices in TOP contracts in Europe and Asia. European gas companies have therefore tended to buy on spot markets, sometimes even failing to take the minimum quantities agreed upon in their long-term contracts.

${ }^{17}$ Between August 2008 and November 2009, spot prices were on average around 50\% lower than gas prices indexed to the price of crude oil or petroleum products in the TOP contracts in Europe and Asia.
} 
contracts amended and according to the specialized press the German companies (E.ON, Wintershall, Wingas and WIEH) have obtained concrete results with respect to both prices and volumes, although details of these supposed agreements are not known ${ }^{18}$ and have not been confirmed by Gazprom. Even if Gazprom makes such changes to only a small number of its contracts, for a limited period of time and for only part of the exported volumes, the introduction of spot prices in the price formula represents a marked change in its strategy. The company has always staunchly defended long-term contracts and oil-indexed prices (Finon and Locatelli, 2006), and it is continuing to do so despite the current adjustments ${ }^{19}$.

\section{II.4 Developing cooperation with other exporting countries?}

This new - and more competitive - gas market configuration raises once again the question as to the viability of the project to create a "gas OPEC", an organization promoted by a number of Europe's major suppliers grouped together in a gas forum. Certain countries have been particularly keen to develop a coordinated policy for gas production in order to limit output and bolster prices ${ }^{20}$. The flexibility that has been introduced into contracts by certain producers shows that coordination of efforts and cohesion within the gas exporters forum is far from being achieved. However, flexibility in long-term contracts, and even their partial replacement by short-term contracts, may open the way to coordinated actions from producers on the spot markets in order to bolster prices ${ }^{21}$, an impossible scenario in the context of longterm contracts. For the specialized press ${ }^{22}$, producers had started to coordinate their policies (sales have been falling since May 2010) and concomitantly spot prices in Europe, to a certain extent, have been adjusted.

\section{Security in gas relations between Russia and the EU}

In addition to all the economic and legal issues concerning gas trading, in the last few years questions of security have also come to the fore. Relations and negotiations between the EU and Russia are largely coloured by these questions, which essentially concern two central contrasting notions - that of supply security, a concern voiced by the EU, and that of demand security raised by Russia, following in the footsteps of OPEC for oil.

\section{III.1 Security of supply versus security of demand}

\footnotetext{
18 'Gazprom amends E.ON contract' Argus, FSUE, 29 January 2010; 'Gazprom 'defines Take or Pay', Argus FSUE, 13 November 2009. According to Argus, amendments to the long-term contract concluded with E. ON will remain in force until 2013 and will allow the German company to purchase $3.2 \mathrm{Gm}^{3}$ of gas per year from Gazprom at prices linked to spot market prices. This volume represents around $16 \%$ of the maximum volume specified in the long-term contract. 'New German contracts take force’ Argus FSUE, 21 May 2010.

19 A. Medvedev, director of Gazprom Export, was very clear on this point: Take or Pay (ToP) clauses are "unshakable and intouchable”. "Gazprom hits a crossroads with sales outlook in flux", Gas Matters, July-Aug. 2010.

20 ‘First gas OPEC meeting” EU Energy, 231, 23 April 2010.

21 “Gas cartel looms”.- Energy Economist, 342, April 2010.

22 “La Russie et le Qatar ont considérablement réduit l’ampleur du surplus de gaz sur le marché international”, Pétrostratégies, 19 July 2010.
} 
Supply security in a context of gas market liberalization has become a central theme in EU energy policy, along with competitivity and sustainable development (EC, op. cit.). Over the last few years, it has been centered more specifically on the so-called Russian risk. Gazprom's investment strategy and delays in developing new production capacity, along with the different transit disputes with Ukraine, have brought the issue of the reliability of natural gas supplies from Russia to the fore. In this context, the nature of gas relations with Russia has been one of the most highly debated questions in the EU, although no agreement on a joint European position seems to have been reached (Cameron, 2010). The divergences between member states more or less reflect their extremely variable levels of dependence on Russian gas (cf. Table 5). Despite the sometimes deeply contrasting views among the EU states about Europe's gas policy towards Russia, the prevailing tendency seems to be to give priority to gas security since this point still remains a central aspect of Europe’s position.

Table 5: Dependence of some EU countries on gas imports from Russia, in \%

\begin{tabular}{|c|c|c|c|c|c|c|c|}
\hline Germany & Austria & Bulgaria & Estonia & Finland & France & Greece & Italy \\
\hline 43.6 & 71.6 & 100.0 & 100.0 & 100.0 & 22.0 & 67.3 & 29.0 \\
\hline Lithuania & Poland & Czech Rep & Romania & UK & Belgium & Spain & Portugal \\
\hline 100.0 & 80.0 & 77.0 & 77.8 & $0(1)$ & 0 & 0 & 0 \\
\hline Note (1): Gazprom conducted some spot sales on the UK market from time to time. \\
Sources: Gazprom, Report 2009, Moscow; BP Energy statistical review, 2009.
\end{tabular}

In contrast to these concerns about supply security, Russia has its own preoccupations about the security of its markets, particularly if it makes the heavy investments needed to develop new gas fields. EU market liberalization policy and climate policy are creating a certain amount of uncertainty over how much gas each of Europe's suppliers, and Russia in particular, will be asked to deliver.

Paradoxically, in the present context of oversupply, which puts natural gas sellers at a disadvantage, Russia's position concerning the security of its markets in the long term takes on greater importance than in the past when it was used as a strictly political counterargument.

\section{III.2 Access to resources: a strategic objective of the Energy Charter}

The absence of any clear EU-wide policy with respect to Russia has led to the development of bilateral relations with Gazprom and Russia based on competition rules developed within the EU. Thus, as well as increasing the number of suppliers and ensuring the security of import routes, "supply security" in the eyes of the EU means, most importantly, gaining access for its gas companies to the hydrocarbon resources of producing countries. The Energy Charter is the crystallization of a European policy aimed principally at defining a multilateral investment treaty that will guarantee investment upstream in the oil and gas sectors.

The Energy Charter, the first multilateral treaty designed to provide a legal framework for cooperation in energy matters, establishes series of rules governing trade, transit and investment aimed at liberalizing investments and energy flows. The Charter defines an investment framework that can guarantee international investment and also ensure nondiscriminatory conditions for foreign investors (incorporation of certain WTO clauses, such as the most-favoured-nation clause or the national treatment clause, see Haghighi, 2007). The principle of state sovereignty over natural resources is not as such called into question by the Charter. However, the rules pertaining to non-discrimination are not without repercussions. Implicitly, they allow to international oil companies to access to hydrocarbon through a 
multilateral investment framework. Similarly, implicit in the transit protocol ${ }^{23}$ is Gazprom's obligation to provide third parties with access to its pipeline networks ${ }^{24}$, since it establishes the principle of "freedom of transit". This is an important question for the EU in its strategy to diversify its supply sources and promote competition. Potentially, this principle of freedom of transit could concern the transmission of gas from Central Asia to Europe via Russia.

Security aspects such as uninterrupted supply and the reliability of transit routes will probably become less of a problem with time and as geopolitical relations between the EU and Russia improve. But, Europe's vision of free to access to resources, promoted in the Energy Charter, may well remain problematic given the hydrocarbon development model that Russia is planning to implement (Konoplyanik and Wälde, 2006). According to the Russian government, the model for organizing the hydrocarbon industries and structuring the markets that the Charter implies means that it is in profound contradiction with the interests of energy producers (Konoplyanik, 2010). Russia is now tending to promote organizational arrangements that are more in keeping with its institutional environment ${ }^{25}$. The authorities are doing this by imposing tighter, more restricted control over access to the country's hydrocarbon resources. This development is undoubtedly in the spirit of oil nationalism that started to emerge from 2000 onwards (Stevens, 2008). But more importantly the state is attempting to redefine economic incentives for oil companies to ensure that the long-term management objectives for its non-renewable resources are taken into account. This vision is clearly incompatible with the principles set forth in the Charter.

\section{III.3 V. Medvedev's underlying response: upstream assets in exchange for downstream assets}

The method of asset swapping promoted by the Russian government is the product of a statebased approach that gives preference to allowing access to its resources through bilateral relations between gas companies - but nevertheless with the support, and even the involvement, of the states. This approach, which will help Gazprom gain a stronger foothold in the downstream segments in Europe, stems from an industrial logic that is different from the market approach promoted by the EU which is based on a vision of competition and multilateral arrangements. Indeed, Russia seems increasingly determined to make access to its hydrocarbon resources conditional on it being able to acquire assets downstream in importing countries (cf. Box 3). The notion of reciprocity (Belyi, 2009) and special bilateral relations would seem to be the cornerstone of Russia's hydrocarbons strategy. This approach is consistent with the objective of seeking maximum downstream integration in energy importing countries.

\footnotetext{
${ }^{23}$ The Energy Charter transit protocol (2000) specifies the conditions of access to pipelines. It defines principles for determining transit tariffs, available capacity and unauthorized taking during transit.

${ }^{24}$ However, the protocol does not contain rules regarding TPA. Other disagreements on transit between the EU and Russia concern in particular the principles of transit tariff determination, use of available transit capacity and the "Right of first refusal" (where the duration of the supply contract is longer than the duration of the transit contract). For more information cf. Haghighi, 2007.

${ }^{25}$ According to neo-institutional analysis, the institutional environment has a decisive effect on the relative efficiency of the different contractual and organizational frameworks (Brousseau, 2008).
} 


\section{Box 3: Gazprom-BASF agreement of 2009}

The agreement between Gazprom and BASF covers the entire gas chain, including exploration and production activities (in Russia), and transmission and distribution activities (in Germany and certain other European countries). Under the terms of the contract, Wintershall (subsidiary of BASF) receives a 25\% stake minus one share in the Russian company Severneftegazprom which is developing the Yuzhno-Russkoye gas field (expected production capacity of $25 \mathrm{Gm}^{3}$ in 2009) ${ }^{26}$. In exchange, Gazprom will increase its share in Wingas from 35 to 50\% minus one share. A 50/50 joint venture between Gazprom and BASF, called Wingas Europe, is also to be created to market the gas in Europe $^{27}$.

Quite apart from these considerations, the position of the Russian government is that it must find an alternative to the Energy Charter. This will no doubt involve defining a new legal basis (and new standards) for dialogue between Russia and the EU that will better take into account the interests of the producing countries. In April 2009, President Medvedev proposed an alternative to the Charter in a document entitled "Conceptual Approach to the New Legal Framework for Energy Cooperation”28. This document clearly reaffirms a number of the elements that structure current energy policy in Russia, more specifically state sovereignty over natural resources, asset swapping, the need to take into account demand aspects in discussing questions of supply security and to redefine relations between transit countries and the producing countries (Box 4). For the moment, this document is no more than a statement of main principles and objectives and does not propose any rules or standards. Nevertheless, it is an indication of a more global approach from Russia, which, according to T. Gomart (2010), is "contesting the normative power of the EU and aspiring to create alternative options”.

\section{Box 4: Some of the main principles of the Conceptual Approach to the New Legal Framework for Energy Cooperation}

The basic principles

- Mutual responsibility of energy consuming and supplying countries, as well as transit states, in ensuring global energy security;

- Security of supply and security of demand are key aspects of global energy security;

- Unconditional state sovereignty over national energy resources;

- Non-discriminatory access to international energy markets, which should be open and competitive;

- Possibility of non-discriminatory investment in all segments of energy chain;

- Promotion of mutual exchange of assets;

- Non-discriminatory access to energy technologies;

- Promotion of infrastructure projects of great importance for global and regional energy security;

\footnotetext{
${ }^{26}$ Wintershall is also involved in developing a gas field in western Siberia, near Urengoy, through its joint venture with Gazprom Achimgaz.

${ }^{27}$ Similarly, in June 2009, French oil company Total acquired a 49\% stake in a Novatek-owned unit in charge of developing a gas field in Yamal province. In exchange, Total sold a large part of its stake in a Dutch refinery to the Russian oil company Lukoil.

28 This document can be consulted on the Kremlin's official site: http://eng.kremlin.ru/text/docs/2009/04/215305.shtml.
} 
- Coordination of energy policies, principles for regulation in production, transit, consumption, new infrastructure development, all essential for global energy security;

- Creation of warning mechanisms concerning supply, demand and transit.

Transit

The aim is to define mechanisms to ensure reliable uninterrupted energy transit. The essential elements are:

- Definition of principles for establishing reasonable, transparent, non-discriminatory, cost-based transit tariffs;

- Unacceptability of unauthorized interruption or reduction of transit;

- Mechanisms for coordination among parties in order to optimize transit routes;

- Special bodies authorized to address emergency situations;

- Dispute settlement by diplomatic means rather than by arbitration and international courts.

Source: President Medvedev "Conceptual approach to the New legal Framework for Energy Cooperation (Goals and principles)”, 21 April 2009,

http://eng.kremlin.ru/text/docs/2009/04/215305.shtml

The situation resulting from these two approaches is making it difficult for the parties to reach a new partnership agreement. The realism of satisfying mutual interests has thus prevailed and is structuring an "essentially bilateral dialogue", either with gas companies or with individual states, while dialogue with the EU as an entity is hampered by different ideas about how the market and gas industry should be structured. Aside from the question of security, these differences are in fact the expression of a clash of values between the EU and Russia on the type of partnership that they should develop and more specifically on how much emphasis should be placed on the rule of law. The efficiency and effectiveness of certain market institutions are largely dependent on the institutional context in which they operate. The Russian state's renewed control of the hydrocarbons industry, which has put the sector back on its feet and added fresh dynamism, may prove to be in total contradiction with the multilateralism and principles of competition promoted by the Energy Charter and the EU. The challenge now is no doubt to try to develop common approaches that can respond to the concerns and objectives of both parties.

\section{References}

Belyi, A., 2009. Reciprocity as a factor of the energy investment regimes in the EU-Russia energy relations. Journal of World Energy Law \& Business 2, 2, 117-128.

Boussena, S., 1999. New European Gas Market : Gas Strategies of Other Present and Potential Suppliers. The role of Russian and CIS Countries in Deregulated Energy Markets, 1999 International Conference, Moscow International Energy Club, Centre de géopolitique des matières premières-Université Paris Dauphine, Paris, 6-7 December.

Boussena, S., Locatelli, C., 2005. Towards a more coherent oil policy in Russia? Opec Review XXIX, 2, 85-105.

Brousseau, E., 2008. Contracts: From Bilateral Set of Incentives to the Multi-Level Governance of Relations. In Brousseau, E. and Glachant, J-M. (eds.) New Institutional Economics. A Guidebook, Cambridge University Press, Cambridge, pp. 37-66.

Cameron, F., 2010. The Politics of EU-Russia Energy Relations. In Talus, K. and Fratini, P. (Eds). EU-Russia Energy Relations. OGEL collection, Euroconfidential, pp. 25-38.

Chevalier, J.M. and Percebois, J., 2007. Gaz et électricité : un défi pour l'Europe et pour la France. La Documentation française, Paris. 
Eikeland, P., 2007. Downstream natural gas in Europe - High hopes dashed for upstream oil and gas companies. Energy Policy 35, 1, 227-237.

European Commission, 2008. Second Strategic Energy Review - Securing our future [online], November. Available at : http://ec.europa.eu/energy/strategies/2008/2008_11_ser2_en.htm. Consulted 17/09/2010]

Finon, D. and Locatelli, C., 2006. Russian and European gas interdependence: Could contractual trade channel geopolitics?, Energy Policy 36, 1, 423-442.

Gomart, T., 2010. Europe in Russian foreign policy: important but no longer pivotal. Russie.NEI. Visions, 50, IFRI, Paris.

Haghighi, S., 2007. Energy Security: The external Legal Relations of the European Union with Major Oil- and Gas-Supplying Countries. Hart, Oxford.

Hauteclocque, A. de and Glachant, J.M., 2009. Long-term energy supply contracts in European Competition Policy: Fuzzy not Crazy. Energy Policy 37, 12, 5399-5407.

International Energy Agency, 2010. Medium-Term Oil and Gas Markets 2010. OCDE, Paris.

Konoplyanik, A., 2010. A Common Russia-EU Energy Space (The New EU-Russia Partnership Agreement, Acquis Communautaire, the Energy Charter and the New Russian Initiative. In Talus, K. and Fratini, P. (Eds) EU-Russia Energy Relations. OGEL collection, Euroconfidential, 45-102.

Konoplyanik, A. and Wälde, T., 2006. Energy Charter Treaty and its Role in International Energy. Journal of Energy and Natural Resources Law 24, 4, 523-558.

Locatelli, C., 2008. Gazprom's export strategies under the institutional constraint of the Russian gas market. OPEC Energy Review XXXII, 3, 246-264.

Milov, V., 2005. Russian energy sector and its international implication. Institute of Energy Policy, Moscow, March.

Percebois, J., 2008. The supply of natural gas in the European Union. OPEC Energy Review XXXII, 1, 33-53.

Riley, A., 2006. The Coming of the Russian Gas Deficit : Consequences and Solutions. Centre for European Policy Studies, Brussels, Policy Briefing, 116.

Rious, V., 2009. The Design of the Internal Energy Market In Relation To Energy Supply Security and Climate Change. Robert Schuman Centre For Advances Studies, Firenze, EUI Working Paper, 37.

Stern, J., 2009. Future Gas Production in Russia: Is the concern about lack of investment justified? Oxford Institute for Energy Studies, Oxford, NG 35.

Stevens, P., 2008. National Oil Companies and International Oil Companies in the Middle East: Under the Shadow of Government and the Resource Nationalism Cycle. Journal of World Energy Law \& Business 1, 1, 5-29.

Talus, K., 2007. Long term agreements and security of supply-between law and politics. European Law Review 32, 535-547.

Tonjes, C. and De Jong, J., 2007. Perspectives on security of supply in European natural gas markets. CIEP, Clingendael Institute, The Hague, August, Working Paper.

Willems, A., Sul, J. and Benizri, Y., 2010. Unbundling as a Defence Mechanism Against Russia: Is the EU Missing the Point? In Talus, K. and Fratini, P. (Eds). EU-Russia Energy Relations. OGEL collection, Euroconfidential, pp. 227-244. 